\title{
THE PREVALENCE OF ACUTE NEUROPATHIC PAIN AFTER SURGERY IN HOSPITAL OF LITHUANIAN UNIVERSITY OF HEALTH SCIENCES KAUNAS CLINICS
}

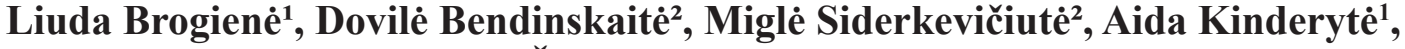 \\ Gintarè Žemgulyte் ${ }^{1}$, Andrius Macas ${ }^{1}$ \\ ${ }^{1}$ Lithuanian University of Health Science, Anaesthesiology department, \\ ${ }^{2}$ Lithuanian University of Health Science
}

Key words: surgery, neuropathic pain, persistent pain, risk factors, postoperative pain, acute pain.

\section{Summary}

Background. Acute neuropathic pain can be one of the post-surgical pain components, which is often under-recognized and complicated to treat. The prevalence of pain with neuropathic characteristics in general population is about $6-8 \%$. Moreover, it might to progress and become as a persistent pain and cause a disability. This type of study has never been performed in Lithuania.

Methods. Investigators conducted a survey, which consisted of the following visual and verbal analogue and Dolour Neuropathique 4 scales to identify pain intensity and neuropathic pain after surgery. Risk factors of neuropathic pain were evaluated with Hospital Anxiety and Depression scale, demographic characteristics and data, which represents possible risk factors.

Results. The survey included 170 participants: 68 males (40\%) and 102 females (60\%). Average age of patients was 59.66 years (SD 15.9). During the first day after surgery $7.1 \%$ patients felt neuropathic pain, on the second day $-8.2 \%$, and the third postoperative day $-7.6 \%$ of patients. A prevalence of neuropathic pain depends on gender and anxiety before surgery.

Conclusion. A prevalence of acute neuropathic pain after surgery in Hospital of Lithuanian University of Health Sciences is $7-8 \%$. The risk factors of neuropathic pain development are patient's gender and anxiety before surgical procedure.

\section{Introduction}

A pain is the most common patient's post-surgical complaint, which worsens the quality of patient's life, healing period, prolongs the of duration hospitalization. Furthermore, it is also a major healthcare and economic problem. Persistent pain often causes functional impairment and disability, psychological distress and sleep disorders [1].

Neuropathic pain is directly related to a lesion or disease, which affects somatosensory system $[2,3]$. This type of pain is classified as a central (outcome after brain or spinal cord damage) and peripheral (as a result of peripheral nerve, plexus, dorsal root ganglion, or root damage) [2]. The most common reasons of central neuropathic pain are the following stroke, spinal cord trauma, multiple sclerosis, phantom pain, whereas a peripheral neuropathic pain is caused by diabetic neuropathy, trigeminal and post-herpetic neuralgia, persistent post-operative and posttraumatic pain, HIV neuropathy and lumbar radiculopathy $[3,4]$. Neuropathic pain may manifest as a paresthesia, dysesthesia and sensory disorders. Meanwhile, patients can describe this pain as a burning, cold or shock like sensation, although some of them cannot describe accurately the pattern of their pain [5]. The prevalence of pain with neuropathic characteristics is approximately $6-8 \%$ in general population $[4,5]$. Treatment of neuropathic pain is a long-term process, which includes the treatment with antiepileptics, antidepressants, local anaesthetic and nonpharmacological methods [2].

Some types of surgery can lead to a persistent pain, including a minor or less invasive procedures, which often presents neuropathic pain features [6]. The frequency of the persistent post-operative pain depends on the extent and invasiveness of the surgical procedure. Certainly, the application of minimally invasive and nerve-sparing tech- 
Table 1. Douleur Neuropathique 4 questionnaire

\begin{tabular}{|c|c|c|}
\hline \multicolumn{3}{|c|}{ Question 1. Does the pain have one or more of the following characteristics? } \\
\hline & Yes & No \\
\hline \multicolumn{3}{|l|}{1 - Burning } \\
\hline \multicolumn{3}{|l|}{2 - Painful cold } \\
\hline \multicolumn{3}{|l|}{3 - Like electric shocks } \\
\hline \multicolumn{3}{|c|}{$\begin{array}{l}\text { Question 2. Is the pain associated with one or more of the following symptoms } \\
\text { in the same area? }\end{array}$} \\
\hline & Yes & No \\
\hline \multicolumn{3}{|l|}{4 - Tingling } \\
\hline \multicolumn{3}{|l|}{$5-$ Pins and needle } \\
\hline \multicolumn{3}{|l|}{6 - Numbness } \\
\hline \multicolumn{3}{|l|}{7 - Itching } \\
\hline \multicolumn{3}{|c|}{$\begin{array}{l}\text { Question 3. Is the pain located in an area where the physical examination } \\
\text { reveals one or more of the following characteristics? }\end{array}$} \\
\hline & Yes & No \\
\hline \multicolumn{3}{|l|}{8 - Hypoesthesia to touch } \\
\hline \multicolumn{3}{|l|}{$9-$ Hypoesthesia to prick } \\
\hline \multicolumn{3}{|c|}{$\begin{array}{l}\text { Question 4. In the painful area, can the pain be caused or increased by brus- } \\
\text { hing? }\end{array}$} \\
\hline & Yes & No \\
\hline 10 - Brushing & & \\
\hline
\end{tabular}

Table 2. The Hospital Anxiety and Depression (HAD) Scale. A: anxiety; D: depression [10]

\begin{tabular}{|c|c|c|c|c|c|}
\hline Statement & Response & Points & Statement & Response & Points \\
\hline \multirow{4}{*}{$\begin{array}{l}\text { I feel tense or wound up } \\
{[\mathrm{A}]}\end{array}$} & None of the time & 3 & \multirow{5}{*}{$\begin{array}{l}\text { I get a sort of frightened } \\
\text { feeling like butterflies in } \\
\text { the stomach } \\
\text { [A] }\end{array}$} & Not at all & 0 \\
\hline & A lot of the time & 2 & & Occasionally & 1 \\
\hline & From time to time, occasionally & 1 & & Quite often & 2 \\
\hline & Not at all & 0 & & Very often & 3 \\
\hline \multirow{4}{*}{$\begin{array}{l}\text { I still enjoy the things I } \\
\text { used to enjoy [D] }\end{array}$} & Definitely as much & 0 & & very onten & 3 \\
\hline & Not quite as much & 1 & \multirow{5}{*}{$\begin{array}{l}\text { I have lost interest in my } \\
\text { appearance } \\
{[\mathrm{D}]}\end{array}$} & Definitely & 3 \\
\hline & Only a little & 2 & & I do not take so much care as I & 2 \\
\hline & Hardly at all & 3 & & should & \\
\hline \multirow{5}{*}{$\begin{array}{l}\text { I get a sort of frightened } \\
\text { feeling as if something } \\
\text { bad is about to happen } \\
\text { [A] }\end{array}$} & Very definnitely and quite badly & 3 & & I may not take quite much care & 1 \\
\hline & Yes, but not too badly & 2 & & I take just as much care as ever & 0 \\
\hline & A little, but it does not worry me & 1 & \multirow{6}{*}{$\begin{array}{l}\text { I feel restless and have to } \\
\text { be on the move }[\mathrm{A}]\end{array}$} & Very much indeed & 3 \\
\hline & \multirow[t]{2}{*}{ Not at all } & \multirow[t]{2}{*}{0} & & Quite a lot & $\begin{array}{l}3 \\
2\end{array}$ \\
\hline & & & & Not very much & 1 \\
\hline \multirow{4}{*}{$\begin{array}{l}\text { I can laugh and see the } \\
\text { funny side of things [D] }\end{array}$} & As much as I always could & 0 & & \multirow[t]{3}{*}{ Not at all } & \multirow[t]{3}{*}{0} \\
\hline & Not quite as much now & 1 & & & \\
\hline & Definitely not so much now & 2 & & & \\
\hline & Not at all & 3 & \multirow{5}{*}{$\begin{array}{l}\text { I look forward with en- } \\
\text { joyment to things } \\
\text { [D] }\end{array}$} & As much as ever I did & 0 \\
\hline \multirow{4}{*}{$\begin{array}{l}\text { Worrying thoughts go } \\
\text { through my mind } \\
\text { [A] }\end{array}$} & A great deal of the time & 3 & & Rather less than I used to & 1 \\
\hline & A lot of the time & 2 & & Definitely less than I used to & 2 \\
\hline & From time to time but not too often & 1 & & \multirow[t]{2}{*}{ Hardly at all } & \multirow[t]{2}{*}{3} \\
\hline & Only occasionally & 0 & & & \\
\hline \multirow{4}{*}{$\begin{array}{l}\text { I feel cheerful } \\
{[D]}\end{array}$} & Not at all & 3 & \multirow{5}{*}{$\begin{array}{l}\text { I get sudden feelings of } \\
\text { panic }[\mathrm{A}] \\
\text {. }\end{array}$} & Very often indeed & 3 \\
\hline & Not often & 2 & & Quite often & 2 \\
\hline & Sometimes & 1 & & Not very often & 1 \\
\hline & Most of the time & 0 & & Not at all & 0 \\
\hline \multirow{4}{*}{$\begin{array}{l}\text { I can sit at ease and feel } \\
\text { relaxed } \\
{[\mathrm{A}]}\end{array}$} & Definitely & 0 & & & \\
\hline & Usually & 1 & \multirow{6}{*}{$\begin{array}{l}\text { I can enjoy a good book } \\
\text { or radio or TV pro- } \\
\text { gramme } \\
{[D]} \\
\cdot \\
\text {. }\end{array}$} & Often & 0 \\
\hline & Not often & 2 & & Sometimes & 1 \\
\hline & Not at all & 3 & & Not often & 2 \\
\hline \multirow{4}{*}{$\begin{array}{l}\text { I feel as if I am slowed } \\
\text { down } \\
\text { [D] }\end{array}$} & Nearly all the time & 3 & & \multirow[t]{3}{*}{ Very seldom } & \multirow[t]{3}{*}{3} \\
\hline & Very often & 2 & & & \\
\hline & Sometimes & 1 & & & \\
\hline & Not at all & 0 & & & \\
\hline
\end{tabular}

niques decreases the risk of persistent post-operative pain. In addition, important risk factors for persistent post-operative pain development can be also insufficiently treated post-operative pain of high acute intensity, young patient's age, long-lasting surgical procedure and genetic predisposition [3]. A lot of studies have investigated neuropathic pain and found out that a management of chronic neuropathic pain is challenging and more than $50 \%$ patients experience only partial or no pain relief [4]. This type of study has never been performed in Lithuania. We decided to assess the neuropathic pain prevalence after various surgeries in Hospital of Lithuanian University of Health Sciences Kaunas Clinics (HLUHSKC).

Aims of the study: to assess the prevalence of neuropathic pain after Orthopaedics and Traumatology, Obstetrics and Gynaecology, General and Urology surgeries in HLUHSKC and evaluate risk factors of neuropathic pain. 


\section{Materials and Methods}

The data was collected during elective surgeries in the HLUHSKC Orthopaedics and Traumatology, Obstetrics and Gynaecology, General surgery and Urology department's from February to June in 2015. 170 patients were questioned during this period. Post-operative pain was managed according to HLUHSKC Anaesthesiology Department post-operative pain management protocol. Exclusion criteria were the following: patients who refused or were not be able to complete survey. Patients were questioned by the authors. The Douleur Neuropathique 4 (DN4) questionnaire for neuropathic pain evaluation was used in this survey, which has been well evaluated in numerous studies (Table 1) [7, 8].

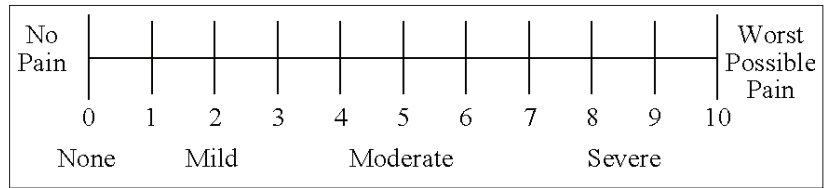

Fig. 1. Visual and verbal analogue scales

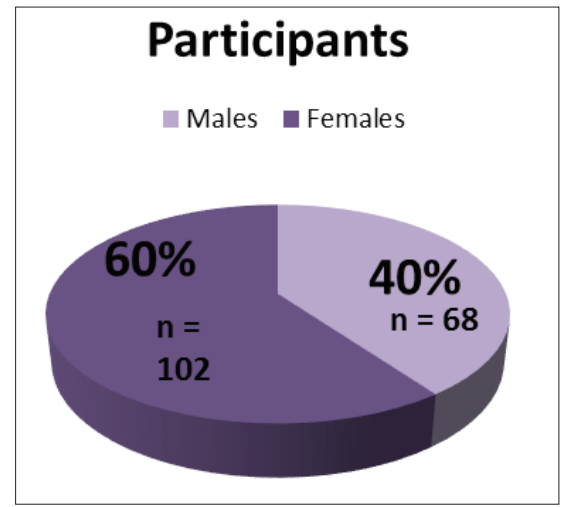

Fig. 2. Distribution by gender

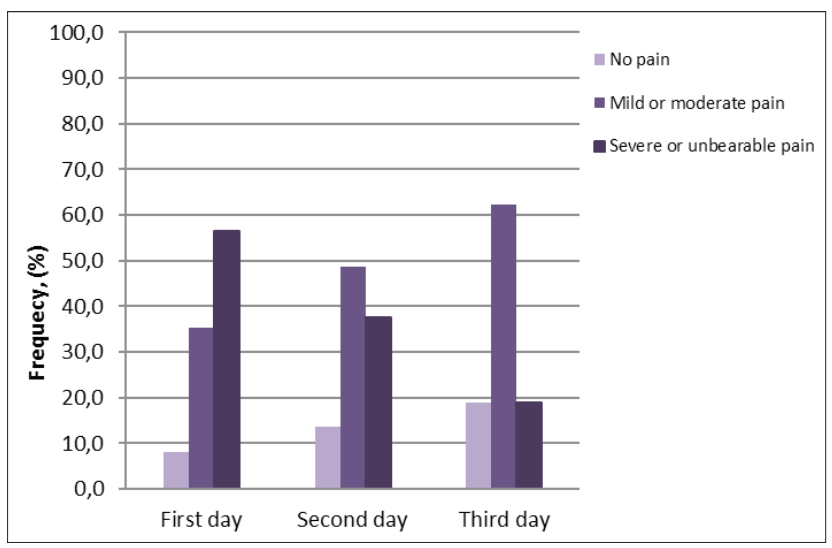

Fig. 3. Pain intensity after surgery
Pain intensity was assessed according to the visual and verbal analogue scales (VAS) after 24, 48 and 72 hours after surgery (Fig. 1). Pain was evaluated according to this pattern: 0 point - no pain, $1-3$ points - mild pain, $4-6$ points - moderate pain, $7-8$ points- severe pain and $9-10$ points - unbearable pain [9].

Anxiety and depression were evaluated according to the Hospital Anxiety and Depression scale. Severity of anxiety and depression was divided to classes: normal (0-7 points), mild anxiety and depression symptoms (8-10 points), moderate anxiety and depression symptoms (11-14 points), and severe anxiety and depression symptoms (1521 points) (Table 2 ).

The statistical data analysis was performed with Statistical Package for Social Sciences (SPSS) 22.0 and Microsoft Office Excel 2010.Chi square and Pearson correlation coefficient tests were used for evaluation of statistical significance, $\mathrm{p}<0.05$.

\section{Results}

The survey included 170 participants: 68 males (40\%) and 102 females (60\%) (Fig.2).

Average age of patients was 59.66 years (SD 15.9). The

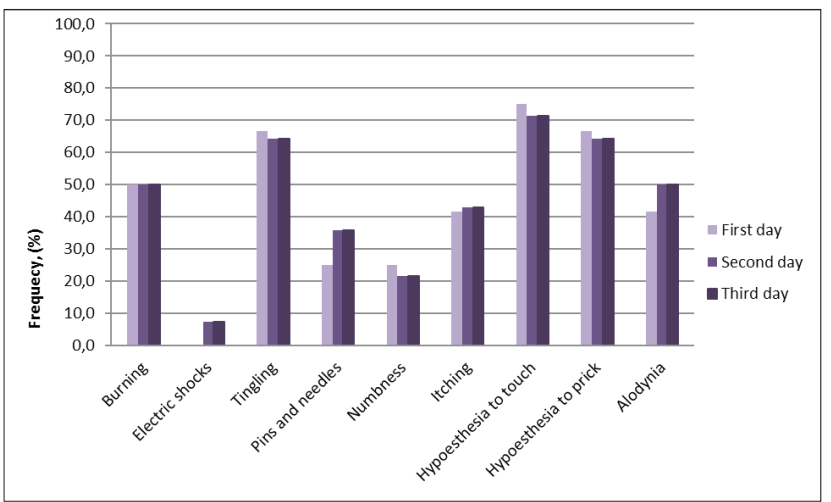

Fig. 4. Characteristics of neuropathic pain

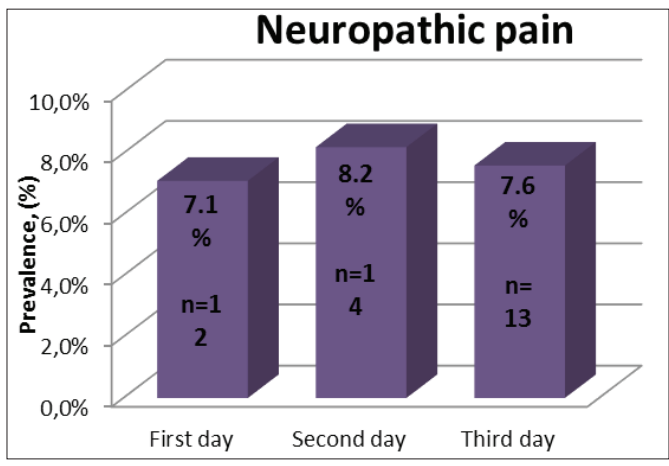

Fig. 5. The prevalence of acute neuropathic pain 
Table 3. Surgical procedure reliance with pain intensity

\begin{tabular}{|c|c|c|c|c|c|c|c|c|c|}
\hline & \multicolumn{3}{|c|}{ First day } & \multicolumn{3}{|c|}{ Second day } & \multicolumn{3}{|c|}{ Third day } \\
\hline & \multicolumn{9}{|c|}{ Visual and verbal scales } \\
\hline & $\begin{array}{c}0 \text { point } \\
\text { (p) }\end{array}$ & $1-6 p$ & $7-10 p$ & $\mathbf{0 p}$ & $1-6 p$ & $7-10 p$ & $\mathbf{0 p}$ & $1-6 p$ & $7-10 p$ \\
\hline & n (\%) & n (\%) & n (\%) & n (\%) & n (\%) & n (\%) & n (\%) & n (\%) & n (\%) \\
\hline $\begin{array}{l}\text { Orthopaedics and } \\
\text { Traumatology } \\
(n=49)\end{array}$ & $\begin{array}{c}4 \\
(8.2)\end{array}$ & $\begin{array}{c}18 \\
(36.7)\end{array}$ & $\begin{array}{c}23 \\
(55.1)\end{array}$ & $\begin{array}{c}5 \\
(10.2)\end{array}$ & $\begin{array}{c}26 \\
(53.1)\end{array}$ & $\begin{array}{c}18 \\
(36.7)\end{array}$ & $\begin{array}{c}8 \\
(16.3)\end{array}$ & $\begin{array}{c}30 \\
(61.2)\end{array}$ & $\begin{array}{c}11 \\
(22.4)\end{array}$ \\
\hline $\begin{array}{l}\text { Obstetrics and } \mathbf{G y}- \\
\text { naecology } \\
(n=38)\end{array}$ & $\begin{array}{c}1 \\
(2.6)\end{array}$ & $\begin{array}{c}9 \\
(23.7)\end{array}$ & $\begin{array}{c}28 \\
(73.7)\end{array}$ & $\begin{array}{c}1 \\
(2.6)\end{array}$ & $\begin{array}{c}16 \\
(42.1)\end{array}$ & $\begin{array}{c}21 \\
(55.3)\end{array}$ & $\begin{array}{c}2 \\
(5.3)\end{array}$ & $\begin{array}{c}30 \\
(78.9)\end{array}$ & $\begin{array}{c}6 \\
(15.8)\end{array}$ \\
\hline $\begin{array}{l}\text { Urology } \\
(n=18)\end{array}$ & $\begin{array}{c}4 \\
(22.2)\end{array}$ & $\begin{array}{c}8 \\
(44.4)\end{array}$ & $\begin{array}{c}6 \\
(33.3)\end{array}$ & $\begin{array}{c}8 \\
(44.4)\end{array}$ & $\begin{array}{c}10 \\
(55.6)\end{array}$ & 0 & $\begin{array}{c}9 \\
(50.0)\end{array}$ & $\begin{array}{c}9 \\
(50.0)\end{array}$ & 0 \\
\hline $\begin{array}{l}\text { General surgery } \\
(n=65)\end{array}$ & $\begin{array}{c}5 \\
(7.7) \\
\end{array}$ & $\begin{array}{c}25 \\
(38.5) \\
\end{array}$ & $\begin{array}{c}35 \\
(53.8) \\
\end{array}$ & $\begin{array}{c}9 \\
(13.8) \\
\end{array}$ & $\begin{array}{c}31 \\
(47.7)\end{array}$ & $\begin{array}{c}25 \\
(38.5) \\
\end{array}$ & $\begin{array}{c}13 \\
(20.0)\end{array}$ & $\begin{array}{c}37 \\
(56.9)\end{array}$ & $\begin{array}{c}15 \\
(23.1) \\
\end{array}$ \\
\hline
\end{tabular}

Table 4. Characteristics and risk factors of development of patients with acute neuropathic pain after surgical procedure during the first 24, 48 and 72 hours

\begin{tabular}{|l|l|l|}
\hline \multicolumn{2}{|l|}{ Patient characteristics } & p value \\
\hline Mean age (years) & $\mathbf{5 9 . 6 6} \pm \mathbf{5 . 9}$ & \\
\hline Gender, F/M, n (\%) & $\mathbf{1 0 2}(\mathbf{6 0}) / \mathbf{6 8}(\mathbf{4 0})$ & \\
\hline $\begin{array}{l}\text { Neuropathic pain depends on gender } \\
\text { (F/M) and anxiety before surgery: }\end{array}$ & & \\
- The first day, n (\%) & $9(75.0) / 3(25.0)$ & 0.038 \\
- The second day, n (\%) & $9(64.3) / 5(35.7)$ & 0.032 \\
- The third day, n (\%) & $9(69.2) / 4(30.8)$ & 0.035 \\
No anxiety / anxiety before surgery: & $4(33.3) / 8(66.7)$ & 0.05 \\
- The first day, n (\%) & $7(50.0) / 7(50.0)$ & 0.046 \\
- The second day, n (\%) & $6(46.2) / 7(53.8)$ & 0.048 \\
- The third day, n (\%) & & \\
\hline $\begin{array}{l}\text { Anxiety among genders (F/M): } \\
\text { - No anxiety, n (\%) }\end{array}$ & $62(60.8) / 52(76.5)$ & 0.033 \\
- Anxiety before surgery, n (\%) & $40(39.2) / 16(23.5)$ & \\
\hline
\end{tabular}

youngest patient was 18 years old and the eldest was 88 years old.

Pain intensity was evaluated with visual and verbal analogue scales. During the first day after surgical procedure majority of patients felt severe or unbearable pain $-56.5 \%(n=96), 35.3 \%(n=60)$ of patients felt mild or moderate pain and merely $8.2 \%$ (14) patient felt no pain at all. In the second day after procedure accordingly $37.6 \%$ $(n=64)$ felt severe or unbearable pain, $48.8 \%(n=83)$ - mild or moderate pain and $13.5 \%(\mathrm{n}=23)$ - no pain, respectively. During the third day $18.8 \%(\mathrm{n}=32)$ felt severe or unbearable pain, $62.4 \%(\mathrm{n}=106)$ - mild or moderate pain and $18.8 \%(\mathrm{n}=32)$ - no pain (Fig. 3), respectively.

Surgery type relationship with pain intensities showed in the table3.

DN4 scale was used to evaluate neuropathic pain. The characteristics of neuropathic pain are given in the figure 4 .

Fig. 4. Characteristics of neuropathic pain

During the first day after surgery $7.1 \%$ patients felt neuropathic pain, on the second day $-8.2 \%$, and the third postoperative day $-7.6 \%$ of patients (Fig.5), respectively.

Results showed that a prevalence of neuropathic pain depends on gender and anxiety before surgery. Females tend to feel stronger neuropathic pain, anxiety before surgical procedure leads to increased risk of neuropathic pain as well. To sum up, females experience anxiety more often than males before surgery (Table 4).

Table 4. Characteristics and risk factors of development of patients with acute neuropathic pain after surgical procedure during the first 24 , 48 and 72 hours

The results of this study did not show any statistical significance of risk factors such as a sleeping disorders, tachycardia, diabetes mellitus, medications used before surgery, anaesthesia type, ASA class, surgical type and duration, pain intensity before operation [11].

\section{Conclusion}

1. The prevalence of neuropathic pain after surgery in the HLUHSKC after Orthopaedics and Traumatology, Obstetrics and Gynaecology, General surgery and Urology procedures is approximately $7-8 \%$.

2. Neuropathic pain depends on patient's gender and anxiety before surgery.

\section{Discussion}

Nowadays a prevalence worldwide of acute neuropathic pain during post-operative period has received higher attention in the scientific 
sources of literature. In 2014, the research performed by P. Jain at all, which undertook 300 patients with various types of cancer surgeries showed that a prevalence of acute neuropathic pain was $10 \%$, whereas the results of this study showed that approximately $7-8 \%$ of patients had characteristics of acute neuropathic pain [12]. Acute neuropathic pain often leads to development of chronic neuropathic pain. According to the index developed by Althaus et al, five predictors contribute to a chronic post - surgical pain (CPSP): pre - operative pain in the area which is to be operated upon, chronic pre - operative pain elsewhere in the body, acute post - operative pain, capacity to overload and comorbid stress symptom such as anxiety, rumination, magnification and helplessness [13].

More intense post - operative pain is observed in association with central sensitisation, younger age, obesity and female gender, also, furthermore severe acute pain is a major risk factor for the development of CPSP [14]. The type of surgery will also affect the severity of acute pain. More than $50 \%$ of patients report severe pain during the first three post - operative days and this can predispose to CPSP [15].Emotional and attentional mechanisms of pain processing already known to play a role in chronic pain conditions have recently attracted interest in perioperative conditions $[16,17]$. Investigators found out that depression or anxiety are related with occurrence of neuropathic pain, but other diseases (for example, diabetes mellitus)are not related to nerve injuries. These contradictions may be related to small sample size.

At present, there is no consensus discussing about the optimal assessment and therapeutic strategy for post-operative neuropathic pain. It may be caused by poor recognition of neuropathic pain as a disease, not just a symptom, although difficulties in establishment of diagnosis or inadequate quantity of reliable clinical trials, concerning recognition and treatment of acute post-operative pain.

For the future extensive studies based on acute neuropathic pain after different procedures with accountability of all contributing factors are needed.

There are some limitations of this study. First of all, no preoperative neuropathic screening was performed. Secondly, no relationship with administrated anaesthesia and perioperative analgesia were studied. Furthermore, the sample of research is quite small. It could be related with short duration of study. In order to improve results, this or similar studies should be continued.

\section{References}

1. Rosenquist EWK. Definition and pathogenesis of chronic pain. Available from URL: http://www.uptodate.com/contents/ definition-and-pathogenesis-of-chronic-pain [2016-10-03]

2. Haanpaa M, Treede RD. Diagnosis and classification of neuropathic pain. Pain: Clin Updates 2010; 18(7): 2-6.

3. Szczudlik A, Dobrogowski J, Wordliczek J. Diagnosis and management of neuropathic pain: Review of literature and recommendations of the Polish Association for the Study of Pain and the Polish Neurological Society - Part Two. Neurologiai Neurochirurgia Polska 2014; 48(6): 423-435.

http://dx.doi.org/10.1016/j.pjnns.2014.11.002

4. Raja SN, Wallace M. Neurostimulation for Neuropathic Pain: Outcomes and New Paradigms. Pain: Clin Updates 2015; 23(5): $1-8$.

http://dx.doi.org/10.1097/j.pain.0000000000000112

5. Magrinelli F, Zanette G, Tamburin S. Neuropathic pain: diagnosis and treatment. PractNeurol 2013; 13: 292-307.

http://dx.doi.org/10.1136/practneurol-2013-000536

6. Lavand P. Chronic pain after surgery: State of the art. Presse Med. 2015; 44(5):486-91.

7. Spallone V, Morganti R, D'Amato C, Greco C, Cacciotti L, Marfia G. A.Validation of DN4 as a screening tool for neuropathic pain in painful diabetic polyneuropathy. Diabetic Medicine 2012; 29(5): 578-585.

http://dx.doi.org/10.1111/j.1464-5491.2011.03500.x

8. Timmerman H, Wilder-Smith O, Can Weel C, WolffA, Vissers $\mathrm{K}$. Detecting the neuropathic pain component in the clinical setting: a study protocol for validation of screening instruments for the presence of a neuropathic pain component. BMC Neurology 2014; 14 (94).

http://dx.doi.org/10.1186/1471-2377-14-94

9. Sekiyama H. Pain intensity scales and assessment of cancer pain. Masui. 2011; 60(9): 1053-8.

10. Norton S, Cosco T, Doyle F, Done J, Sacker A. The hospital anxiety and depression scale: a meta confirmatory factor analysis. Journal of Psychosomatic Research 2013; 74: 74-81.

http://dx.doi.org/10.1016/j.jpsychores.2012.10.010

11. Mc Greevy K, Bottros MM, Raja SN. Preventing chronic pain following acute pain: risk factors, preventive strategies, and their efficacy. European Journal of Pain Supplements 2011; 5(2): 365-372.

http://dx.doi.org/10.1016/j.eujps.2011.08.013

12. Jain P, Padole D, Bakshi S. Prevalence of acute neuropathic pain after cancer surgery: A prospective study. Indian Journal of Anaesthesia 2014; 58(1): 36-42.

http://dx.doi.org/10.4103/0019-5049.126788

13. Althaus A, Hinrichs-Rocker A, Chapman R. et al. Development of a risk index for the prediction of chronic post-surgical pain. Eur J Pain 2012; 16: 901-910. http://dx.doi.org/10.1002/j.1532-2149.2011.00090.x

14. Puolakka PA, Rorarius MG, Roviola M. et al. Persistent pain following knee arthroplasty. Eur J Anaesthesiol 2010; 27 : 455-460. 
http://dx.doi.org/10.1097/EJA.0b013e328335b31c

15. Wylde V, Rooker J, Halliday L, Blom A. Acute postoperative pain at rest after hip and knee arthroplasty: severity, sensory qualities and impact on sleep. Orthop Traumatol Surg Res 2011; 97: 139-144.

http://dx.doi.org/10.1016/j.otsr.2010.12.003

16. Holmes A, Williamson O, Hogg M. et al. Predictors of pain 12 months after serious injury. Pain Med 2010; 11:1599-1611. http://dx.doi.org/10.1111/j.1526-4637.2010.00955.x

17. Lautenbacher S, Huber C, Schofer D. et al. Attentional and emotional mechanisms related to pain as predictors of chronic postoperative pain: a comparison with other psychological and physiological predictors. Pain 2010; 151: 722-731.

http://dx.doi.org/10.1016/j.pain.2010.08.041

\section{POOPERACINIO ŪMINIO NEUROPATINIO SKAUSMO PAPLITIMAS LIETUVOS SVEIKATOS MOKSLŲ UNIVERSITETO LIGONINĖS KAUNO KLINIKOSE}

L. Brogienė, D. Bendinskaitė, M. Siderkevičiutė, A. Kinderytė, G. Žemgulytẻ A. Macas

Raktažodžiai: chirurgija, neuropatinis skausmas, lètinis skausmas, rizikos veiksniai, pooperacinis skausmas, ūminis skausmas.
Santrauka

Ivadas. Ūminis neuropatinis skausmas yra vienas iš pooperacinio skausmo kompenentų, kuris dažnai nediagnozuojamas, todèl negydomas. Be to, gali tapti lètiniu skausmu ir negalios priežastimi. Toks tyrimas nèra atliktas Lietuvoje.

Metodika. Tyrime naudotos neuropatiniam skausmui nustatyti po operacijos vizualinè analoginè ir neuropatinio skausmo skalès. Rizikos veiksnių nustatymui naudota nerimo ir depresiškumo skalè, rinkti demografiniai ir kiti duomenys, nurodantys galimus rizikos veiksnius.

Rezultatai. Tyrime dalyvavo 170 tiriamujų - 68 (40 proc.) vyrai ir 102 (60 proc.) moterys. Amžiaus vidurkis $-59,66 \pm 15,9 \mathrm{~m}$. Pirmą dieną po operacijos 7,1 proc., antrą dieną $-8,2$ proc., trečią dieną $-7,6$ proc. tiriamujų vargino neuropatinis skausmas. Neuropatinio skausmo atsiradimas priklauso nuo paciento lyties ir nerimo prieš operaciją.

Išvados. Atliktame tyrime nustatyta, kad Lietuvos sveikatos mokslų universiteto ligoninèje Kauno klinikose ūmaus neuropatinio skausmo paplitimas po operacijos yra $7-8$ proc.

Adresas susirašinèti: liuda.janauskaite@gmail.com

Gauta 2016-10-18 